\title{
Effect of Different Rates on Growth Performance, Feed Utilization and Body Composition for Mixed Sex Nile Tilapia (Oreochromis Niloticus) Reared in Tanks
}

\author{
Yones A M ${ }^{1 *}$, Hussein $\mathrm{M} \mathrm{S}^{2}$, Metwalli $\mathrm{AA}^{1}$ and Lotfy $\mathrm{AM}^{2}$ \\ ${ }^{1}$ National Institute of Oceanography and Fishers, Egypt \\ ${ }^{2}$ Department of Animal Production, Al-Azhar University, Egypt
}

Submission: October 10, 2019; Published: November 14, 2019

Corresponding author: Yones A M, National Institute of Oceanography and Fishers, Egypt

\begin{abstract}
The fishes used in this study were mixed Nile tilapia (Oreocheromis niloticus) fingerlings. The experimental fish were transported to the experimental station through Plastic bags and pout in aquarium tanks. Fish were fed on a commercial diet containing (Cp) $30 \%$ protein. The experimental system consists of 12 tanks with a total volume of $50 \mathrm{~L}^{3}$ for each tank. Three replicates were used for each treatment. Each tank was supplied with compressed air pump with tube via air stones. The temperature was adjusted at $27 \pm 1{ }^{\circ} \mathrm{C}$ by using thermostatically controlled heaters. The experiment duration was 90 days. The feeding rate was applied in four treatments as $3 \%$ (control), $1 \%, 5 \%$ and $7 \%$ of live body weight. Fish were fed 6 day/week the results were summarized as:
\end{abstract}

- By using 3\% feeding rate highest survival rate (100\%) was obtained, followed by 98 in each feeding rate 5 and $7 \%$, where the least survival was obtained with $1 \%$.

- Regarding growth parameter: the highest finial weight of tilapia fish without significance difference $(\mathrm{P}<0.05)$ with all feeding rates was recorded by using $3 \%$ feeding rate. However, least final weight was recorded in fish received $1 \%$ feeding levels. specific growth rate(SGR) and condition factor( $(\mathrm{CF})$, where fish fed $3 \%$ group recorded higher value $(\mathrm{P}<0.05)$ compared to the other treatments.

- The effect of feeding rate on feed utilization: the highest finial weight $(\mathrm{FW})$ of tilapia fish with significance difference $(\mathrm{P}<0.05)$ with all feeding rates was recorded by using $3 \%$ feeding rate. So, the NPU\% values, the groups fed $3 \%$ showed increased value and significantly $(\mathrm{P}<0.05)$ with the other tested groups.

- The carcass analysis in terms of crude protein (CP) and ash not significantly different between tested feeding rate, where whole fish body lipid was increased by the increasing feeding rate in treatments 5 and $7 \%$, without significance difference between the two feeding rates.

The present results confirmed an enhancement in growth performance and feed utilization by using $3 \%$ feeding rate in Nile.

Keywords: Nile tilapia; Body composition; Survival rate; Reared; CP; NPU

\section{Introduction}

Fresh water is one of our most precious natural resources. The present trend of global food security in aquaculture, which is focused on increasing the protein intake of every individual, can only be attained through proper water management [1]. However, the problem of water scarcity in Egypt, especially fresh water, has become one of the main problems facing the expansion of aquaculture, so it was the motive that inspired the idea of this research, which is how to make use of water or rationalize its use in the process of aquaculture so that we can get good fish free from pollution with minimal amount of water and minimal material costs [2]. Feed is one of the most important criteria for aqua farming.
Feed costs contribute substantially to the operating cost of commercial fish production, and this expense may make the difference between profitable and unprofitable culture enterprises [3]. In aquaculture, $60 \%$ of the production cost is incurred as feed [4]. In extensive and semi intensive system, natural food like planktons and bottom organisms play the most vital role in fish production.

Egypt is one of the major contributors to the world aquaculture projects. Production from both wild and aquaculture fishing are of premium importance on fresh and marine fishes [2]. Aquaculture development has accelerated throughout the countries, since 1982, it has accounted for more than $70 \%$ aquatic produc- 
tion, of the countries making Egypt the largest producer of aquatic products in Africa and in high rank production in the world. As fast-growing sector, the desire for more and efficient production with minimal hindrances forced the producers to seek for health strategies that medley both fish and consumers. Globally, aquaculture is expanding into new intense and diverse directions. With the increasing of production manipulation, production obstacles appear among which, disease problems that are of premium importance [5]. Tilapia has become the shining star of aquaculture and popularly known as 'aquatic chicken. Tilapia culture is popular in tropical, sub-tropical and temperate regions. Tilapia is being farmed in about 120 countries and second in sales and volume in international trade after salmonids. Genetically Improved Farmed Tilapia (GIFT) farming technology is a major milestone in the history of tilapia aquaculture [6].

The optimum protein requirement of Nile tilapia depends on size, age, and water temperature. Several studies have been estimated that protein requirement for juvenile tilapia varies from 32 to $50 \%$ and for larger tilapia 25 to $30 \%$ [7-13]. Tilapia utilize starch efficiently from 22 to $46 \%$ dietary starch while $22 \%$ considered as optimum level for juvenile tilapia [14]. So, the growth of tilapia can be enhanced by using optimum protein, lipid, carbohydrate and other nutrients also has similar type influence on growth performance of tilapia. Therefore, the present study was designed to investigate the effects of optimal feeding rate on growth performance, feed utilization and body composition for Nile tilapia (Oreochromis niloticus) reared in tanks at fixed feeding frequency.

\section{Materials and Methods}

\section{Fish Culture and Experimental Conduction}

The fishes used in this study were mixed Nile tilapia (Oreocheromis niloticus) fingerlings. They were obtained from the fish farms of the inland Branch of the National Institute of Oceanography and Fisheries (El Kanater El Khayria, Kaluobia Governorate, Ministry of scientific Research) Egypt. The experimental fish were transported to the experiential glass aquarium tanks. Fish size was 6.7-7.1 g/fish and body length $2.8-2.9 \mathrm{~cm}$, the batch of fish was kept in indoor tanks for two weeks as an acclimatization period. Fish were fed on a commercial diet containing 30\% protein during the acclimatization period before starting the experiment. The experimental system consists of 12 tanks with a total volume of $50 \mathrm{~L}^{3}$ for each tank. Three replicates were used for each treatment. Physicochemical characteristics of water tank was examined every two weeks according to [15].

\section{Experimental Design}

The present experimental was designed to test a commercial diet. Fishes were randomly distributed into the experimental tanks at stocking rate of (15fish/tank). The water carrying capacity of each tank was 50 liters. Each tank was supplied with compressed air pump and the air was pumped through plastic tube via air stones. The temperature was adjusted at $27 \pm 1^{\circ} \mathrm{C}$ by using thermostatically controlled heaters. The experiment duration was 90 day (from $1^{\text {st }}$ Novamber, 2017 until 1st, Febrawary,2018).

\section{Experimental Diet and Feeding Protocol}

Feed formulation and chemical composition of the ingredients and experimental diet were presented in (Tables 1,2). The feeding rate was applied in four treatments as $3 \%$ (control), 1\%,5\% and $7 \%$ of live body weight. Fish were fed 6 day/week and the amount of feed was divided into two equal portions at (10:00p.m and 4:00a.m). Fish were weighed every two weeks (to minimize the effect of handling) as reported by Windell et al. and El-Banna $[16,17]$.Total weight was determined to the nearest gram and the fish immediately returned to their tank conditions and the feed amounts were adjusted and corrected according their new weight [18].

Table 1: Proximate composition of feed ingredients (\% DM basis).

\begin{tabular}{|c|c|c|c|c|c|c|}
\hline Ingredients & DM\% & CP\% & EE\% & NFE\% ${ }^{1}$ & CF\% & Ash \\
\hline Fish meal & 91.5 & 70 & 12.4 & - & - & 17.6 \\
\hline Soya bean meal & 91.7 & 45.5 & 4.6 & 38.3 & 4.2 & 4.6 \\
\hline Yellow-Corn & 90.1 & 8.2 & 2.1 & 77.5 & 5.6 & 6.6 \\
\hline Wheat bran & 90.1 & 14.2 & 3.6 & 66.4 & 9.2 & 6.6 \\
\hline
\end{tabular}
$[100-(C P+E E+C F+A s h)]$.

Table 2: Formulation and proximate composition of experimental diet (\% DM basis).

\begin{tabular}{|c|c|}
\hline Ingredients & $\%$ \\
\hline Fish meal & 10 \\
\hline Soya bean meal & 40 \\
\hline Yellow-Corn & 19.3 \\
\hline Wheat bran & 24.25 \\
\hline Di-calcium phosphate & 2 \\
\hline Fish oil & 1.9 \\
\hline Binder & 2 \\
\hline Vitamin premix1 & 0.25 \\
\hline Mineral premix1 & 0.05 \\
\hline Vitamin C & 0.25 \\
\hline \multicolumn{2}{|l|}{ Proximate composition (\%DM basis) } \\
\hline Crude Protein & 30.22 \\
\hline Crude lipid & 20 \\
\hline N.F.E & 38.85 \\
\hline Crude fiber & 3.96 \\
\hline Ash & 6.97 \\
\hline GE/ MJ kg ${ }^{-1}$ diet $^{2}$ & 22.01 \\
\hline $\mathrm{ME} / \mathrm{MJ} \mathrm{kg}{ }^{-1} \operatorname{diet}^{3}$ & 18.11 \\
\hline
\end{tabular}

\section{Sample Collection and Chemical Analysis}

At the start of the experiment, ten stock fish were killed, weighed and kept frozen for subsequent initial whole-body composition analysis. At the end of experiment, fish were removed, counted and weighed. Five fishes from each tank were taken to 
carry out chemical analysis of the fish whole body composition. Subsequently, all these samples were homogenized dried and then ground into powder before chemical Vitamin mineral premix (mg or IU/kg of diet): thiamin,24.5mg; riboflavin,36mg; pyridoxine $\mathrm{HCl}$,19.8mg; vitamin B12,0.1mg; vitamin K3, $5.1 \mathrm{mg}$; inositol,784 mg; pantothenic acid,58.8mg; niacin acid,198 mg; folic acid, 19.6mg; biotin,1.20 mg; retinol acetate,16,000 IU; cholecalciferol, $2500 \mathrm{IU}$; alpha-tocopherol, $200 \mathrm{mg}$; choline chloride (50\%),2500 mg; ascorbic acid (35\%),1000 mg; mold inhibitor,1000mg and ethoxyquin,500mg; $\mathrm{MgSO}_{4} \cdot 7 \mathrm{H}_{2} \mathrm{O}, 1200 ; \mathrm{CuSO}_{4} \cdot 5 \mathrm{H}_{2} \mathrm{O}, 10 ; \mathrm{Zn}$ $\mathrm{SO}_{4} \cdot \mathrm{H}_{2} \mathrm{O}, 50 ; \mathrm{FeSO}_{4} \cdot \mathrm{H}_{2} \mathrm{O}, 80 ; \mathrm{MnSO}_{4} \cdot \mathrm{H}_{2} \mathrm{O}, 45 ; \mathrm{CoCl}(1 \%), 50 ; \mathrm{Na}_{2} \mathrm{SeO}_{3}$ (1\%),20; $\mathrm{Ca}(\mathrm{IO}) 2$ (1\%), 60; Zeolite, 8485 and $\mathrm{Ca}(\mathrm{H} 2 \mathrm{PO}) 2 \cdot \mathrm{H}_{2} \mathrm{O}$, 5000 .

2-Gross energy ( $\mathrm{MJ} \mathrm{Kg}^{-1}$ diet) was calculated by using the following calorific values: 23.9, 39.8 and $17.6 \mathrm{KJ} \mathrm{g}^{-1}$ diet for protein, ether extract and nitrogen free extract, respectively [19]. 3-The metabolizable energy( $\mathrm{MJ} \mathrm{\textrm {Kg } ^ { - 1 }}$ diet) of the experimental diets were calculated as 18.9, 35.7 and $14.7 \mathrm{KJ} \mathrm{g}^{-1}$ diet for protein, lipid and nitrogen free extract, respectively. Composition analysis of ingredients, diet and fish carcasses were carried out according to the methods of AOAC (Association of Official Analytical Chemists 2006). Dry matter $\left(105^{\circ} \mathrm{C}\right.$ to constant weight). Moisture was determined by drying oven at $85^{\circ} \mathrm{C}$ until fixed weight. Crude protein was determined by Kjeldahl method (total nitrogen x 6.25). Total lipids (ether extract) were determined by Soxhlet extraction method using petroleum ether for $16 \mathrm{hrs}$. Ash was determined by put the samples in muffle furnace at $550{ }^{\circ} \mathrm{C}$ for $6 \mathrm{hrs}$.

\section{Calculation of Growth Parameters}

The growth performance and feed utilization parameters were calculated according to the following equation:

- $\quad$ total weight gain (TWG) In $g$ = final weight (g)-initial weight (g)

- $\quad$ Average daily gain (ADG) in g=TWG (g) / Time (days)

- $\quad$ survival rate $(\mathrm{SR} \%)=$ Total Number of fish at the end of the experimental*100/total number of fish at the start of the experiment.

Specific growth rate $($ SGR\%) $=100 \times($ Ln final weight-Ln initial weight)/120.

- Condition factor $(\mathrm{CFg} / \mathrm{cm} 3)=($ wet weight $) /($ total length3) $\times 100$.

- $\quad \mathrm{FCR}=($ feed given per fish) $/$ (weight gain per fish).

- Protein efficiency ratio (PER)=(weight gain per fish)/ (protein intake per fish).

- $\quad$ Net protein Utilization (NPU\%)=100 (Final body protein-initial body protein/protein intake).

- Hepatosomatic index (HSI \%) =(liver weight) $/($ fish weight) $\times 100$.
- $\quad$ Specific growth rate (SGR\%),- Condition factor (CFg/ cm3- FCR

- $\quad$ Protein efficiency ratio (PER-Net protein Utilization (NPU\%)

- $\quad$ Hepatosomatic index (HSI \%)

\section{Statistical Analysis}

The data on fish growth, feed utilization efficiency and whole fish body constituents were subjected to one-way analyses of variance (ANOVAs) to determine whether there was a significant difference $(\mathrm{P}<0.05)$ among fish fed at different protein levels. Differences between means were assessed at the $5 \%$ probability level using Duncan's multiple range test, as described by Steel and Torrie [20]. All analysis was performed using SPSS version 20,(2014) SPSS Institute, Cary, NC, USA), SPS4S [21].

\section{Results and Discussion}

\section{Physicochemical Characteristics}

Table 3: An averages of water physicochemical characteristics parameters of water tanks during experimental period (Mean \pm SD) ${ }^{1}$.

\begin{tabular}{|c|c|c|c|c|}
\hline \multirow{2}{*}{ Parameters } & \multicolumn{4}{|c|}{ Feeding levels \% } \\
\cline { 2 - 5 } & $\mathbf{3}$ & $\mathbf{1}$ & $\mathbf{5}$ & $\mathbf{7}$ \\
\hline $\begin{array}{c}\text { Temperature } \\
\text { oC }\end{array}$ & $28.4 \pm 0.3$ & $28.5 \pm 0.3$ & $28.3 \pm 0.2$ & $28.4 \pm 0.3$ \\
\hline Salinity (g/l) & $0.3 \pm 0.01$ & $0.31 \pm 0.02$ & $0.3 \pm 0.01$ & $0.31 \pm 0.02$ \\
\hline $\mathrm{pH}$ & $7.8 \pm 0.2$ & $7.9 \pm 0.3$ & $7.8 \pm 0.1$ & $7.9 \pm 0.2$ \\
\hline $\begin{array}{c}\text { Dis.Oxy. } \\
(\mathrm{mg} / \mathrm{l})^{2}\end{array}$ & $7.2 \pm 0.1$ & $7.2 \pm 0.1$ & $7.2 \pm 0.1$ & $7.2 \pm 0.1$ \\
\hline $\mathrm{N}-\mathrm{NH} 3(\mathrm{mg} / \mathrm{l})^{3}$ & $0.42 \pm 0.01$ & $0.41 \pm 0.01$ & $0.42 \pm 0.01$ & $0.41 \pm 0.01$ \\
\hline $\mathrm{N}-\mathrm{N} 02(\mathrm{mg} / \mathrm{l})^{4}$ & $0.004 \pm 0.01$ & $0.004 \pm 0.01$ & $0.004 \pm 0.01$ & $0.004 \pm 0.01$ \\
\hline
\end{tabular}

1-Mean values of experimental tanks (3 tanks per each feeding level); 2- Dissolved oxygen;

3- Ammonium nitrate; 4- Ammonium nitrite

Water physicochemical characteristics (Table 3) revealed that temperature, $\mathrm{pH}$, dissolved oxygen, and unionized ammonia are within the optimum ranges for rearing tilapia according to [22]. Similar physicochemical conditions were observed in all ponds of the present study as presented in Table 3 . The average temperature of experimental tanks $28.4^{\circ} \mathrm{C}$ was almost like the optimum range $\left(26-28{ }^{\circ} \mathrm{C}\right)$ in each red tilapia and Nile tilapia [23]. The $\mathrm{pH}$ value (7.85) was also within acceptable limits according to finding of water quality criteria for Nile tilapia. Dissolved oxygen content of all tested feeding levels was found to be within the normal range for this specie. Recommendation level for oxygen is above $3 \mathrm{mg} /$ $\mathrm{L}^{-1}$, TAN 0.5 to $1.0 \mathrm{mg} / \mathrm{L}^{-1}$, [24] and $\mathrm{NO}_{2}$ below $1.0 \mathrm{mg} / \mathrm{L}^{-1}$ [25].

\section{Effect of Feeding rate on Survival}

The 3\% feeding rate rivaled high survival rate $(100 \%)$ followed by 98 in feeding rate 5 and $7 \%$ and the least survival was obtained with $1 \%$.These results support previous findings that juvenile tilapia is more sensitive to feeding rate than larger tilapia and the low feeding rate may be increase mortality in tilapia [26]. 
Also, high feeding rate in the present experiment increase mortality and decrease water quality to a level, where the tilapia suffered notable health problems (Table 4).

\section{Effect of Feeding rate on Growth Parameter}

As presented in Table 4, averages of initial weights ranged between 7.77 to $8.05 \mathrm{~g} /$ fish with insignificant differences among the dietary groups indicating the random distribution of the experimental fish among treatment groups. Concerning growth performance parameters in Table 4 , the highest finial weight of tilapia fish with significance difference $(\mathrm{P}<0.05)$ with all feeding rates was recorded by using 3\% feeding rate. However, a decreased in final weight was obtained with feeding rates 5 and $7 \%$, without significant difference $(\mathrm{P}>0.05)$ between each other. On the other hand, the least final weight was recorded in fish received $1 \%$ feeding levels. The same trend was observed with total gain, daily gain, specific growth rate and condition factor, where fish fed $3 \%$ group recorded higher value $(\mathrm{P}<0.05)$ compared to the other treatments, with significance differences between all tested diets. On the other hand, the tested diets had insignificance differences in total final lengths between all groups.

Table 4: Growth performance mean values (Mean $\pm s d, n=3$ ) of tilapia fed diet $3 \%$ feeding level for 90 days.

\begin{tabular}{|c|c|c|c|c|}
\hline \multirow{2}{*}{ Items Parameters } & \multicolumn{4}{|c|}{ Feeding levels \% } \\
\cline { 2 - 5 } & $\mathbf{3}$ & $\mathbf{1}$ & $\mathbf{5}$ & $\mathbf{7}$ \\
\hline Initial weight (g/fish) & $7.77^{\mathrm{a}} \pm 0.12$ & $7.84^{\mathrm{a}} \pm 0.11$ & $7.82^{\mathrm{a}} \pm 0.12$ & $2.05^{\mathrm{a}} \pm 0.11$ \\
\hline Final weight (g/fish) & $28.01^{\mathrm{a}} \pm 1.21$ & $12.94^{\mathrm{c}} \pm 1.62$ & $24.14^{\mathrm{b}} \pm 1.83$ & $25.83^{\mathrm{b}} \pm 2.12$ \\
\hline Total gain (g/fish) & $20.24^{\mathrm{a}} \pm 1.23$ & $5.1^{\mathrm{c}} \pm 0.1$ & $16.32^{\mathrm{b}} \pm 1.54$ & $17.78^{\mathrm{b}} \pm 0.1$ \\
\hline Average gain (g/fish/d) & $0.22^{\mathrm{a}} \pm 0.01$ & $0.05^{\mathrm{c}} \pm 0.01$ & $0.18^{\mathrm{b}} \pm 0.01$ & $0.19^{\mathrm{b}} \pm 0.05$ \\
\hline Specific growth rate & $1.42^{\mathrm{a}} \pm 0.1$ & $0.56^{\mathrm{c}} \pm 0.02$ & $1.25^{\mathrm{b}} \pm 0.1$ & $1.3^{\mathrm{b}} \pm 0.1$ \\
\hline Condition factor (g/cm3) & $2.63^{\mathrm{a}} \pm 0.2$ & $1.82^{\mathrm{c}} \pm 0.2$ & $2.42^{\mathrm{b}} \pm 0.2$ & $2.32 \pm 0.2^{\mathrm{b}}$ \\
\hline Survival rate \% & 100 & 94 & 98 & 98 \\
\hline
\end{tabular}

Means in the same raw with different super script letters are significantly different $(P<0.05)$.

The growth performance in the present study was agree with the previous results obtained with tilapia [27],who recorded that $3 \%$ feeding rate is optimum for this specie. In the same trend, comparable results were obtained by [28-30]. They recorded that the Nile tilapia fed with $2,7 \%$ feeding rate recorded the highest growth performance. However, other research recorded that $2 \%$ feeding level is optimum in the large size tilapia (66.7-221.1g) in concrete tank [9]. The conflicting results between different studies as a result of different stage and experiential condition. The decrease in growth performance parameters with $1 \%$ feeding rate maybe this value was slightly above the maintenance feeding level. This finding was like which obtained by [31]. In the same manner, the high feeding rate 5 and $7 \%$ showed also a decrease in growth performance due to fish received much feeds (over feeding) and this led to increased rate of feed passage through the digestive tract, thus depressed feed utilization. The results were like the recoded results of [27,32]. Also overfeeding can have a negative effect on growth by abetting the deterioration of water quality [33].

\section{Effect of Feeding rate on Feed Utilization}

Table 5: Feed utilization mean values (Mean $\pm s d, n=3$ ) of tilapia fed on different experimental diets for 90 days.

\begin{tabular}{|c|c|c|c|c|}
\hline \multirow{2}{*}{ Parameters } & \multicolumn{4}{|c|}{ Feeding levels \% } \\
\cline { 2 - 5 } & $\mathbf{3}$ & $\mathbf{1}$ & $\mathbf{5}$ & $\mathbf{7}$ \\
\hline Feed consumed (g/fish) & 33.16 & 20.4 & 50.45 & 70.22 \\
\hline Feed conversion ratio & $1.63^{\mathrm{a}} \pm 0.1$ & $4.0^{\mathrm{c}} \pm 0.2$ & $3.09^{\mathrm{b}} \pm 0.1$ & $3.94^{\mathrm{c}} \pm 0.2$ \\
\hline PER & $2.01^{\mathrm{a}} \pm 0.2$ & $0.82^{\mathrm{c}} \pm 0.1$ & $1.07^{\mathrm{b}} \pm 0.1$ & $0.83^{\mathrm{c}} \pm 0.1$ \\
\hline NPU (\%) & $27.94^{\mathrm{a}} \pm 1.4$ & $10.41^{\mathrm{c}} \pm 1.2$ & $15.09^{\mathrm{b}} \pm 1.2$ & $11.82^{\mathrm{c}} \pm 1.1$ \\
\hline HSI (\%) & $1.8^{\mathrm{b}} \pm 0.2$ & $1.0^{\mathrm{c}} \pm 0.1$ & $2.4^{\mathrm{a}} \pm 0.3$ & $2.6^{\mathrm{a}} \pm 0.3$ \\
\hline
\end{tabular}

Means in the same raw with different super script letters are significantly different $(P<0.05)$.

As can be seen in (Table 5), average amounts of feed consumed were found to be 33.16, 20.4, 50.45 and 70.22g in feeding rate $3,1,5$ and $7 \%$,respectively. The feed intake showed a decrease in feeding level $1 \%$ and tended to increase with 5 and $7 \%$ feeding rates. On the other hand, the best FCR (lowest) values were obtained by the fish fed $3 \%$ feeding rate, which significantly difference $(\mathrm{P}<0.05)$ with the other treatments, followed in an significant $(\mathrm{P}<0.05)$ increasing order (worth) by fish fed 5,7 and
$1 \%$, respectively. As presented in the same tables, the highest PER value (2.01) was obtained by the $3 \%$ feeding rate, followed with insignificance decreasing order by 5 and $7 \%$ feeding rate, where the least significance value was recorded with $1 \%$ feeding rate.

Concerning the NPU\% values, the groups fed 3\% showed increased value and significantly $(P<0.05)$ with the other tested groups, followed with insignificance decreasing order by 5 and $7 \%$ groups. The fish fed $1 \%$ feeding level revealed the least signif- 
icance value between tested groups. Means in the same raw with different super script letters are significantly different $(\mathrm{P}<0.05)$. The highest feed utilization (FCR,PER and NPU) results with using $3 \%$ feeding were comparable to the previous results in tilapia $[9,28,34]$. Also, the reduction in fish fed $1 \%$ was in the same to the results of [35].They concluded that insufficient feeding increases competition between fish, reduces growth and decreases FCR. In the same manner, the hepatosomatic index (HSI) was also differently between feeding rate, where the 5 and $7 \%$ feeding levels showed the highest values among dietary groups without significance difference between each other.

Less significance values $(\mathrm{P}<0.05)$ were found in groups fed 3 and 1\% feeding rate. Relative liver weight (i.e. HSI) was negatively correlated with increasing levels of dietary carbohydrate but there were no significant relationships between HSI, protein intake and $\mathrm{CHO}$ source. Enlargement of liver size and glycogen concentration increased with elevated levels of dietary carbohydrate in several fish [36]. Absorbed carbohydrate that is not used for energy usually accumulated in the liver of fish both as lipid and as glycogen after being converted [37]. This finding is agreed in fish fed with 5 and $7 \%$ feeding rate (overfeeding), where they showed an increase in HIS due to accumulate excess energy in the liver. The present results showed an enhancement in growth performance and feed utilization with usin $3 \%$ feeding rate compared with the other treatments.

\section{Effect of Feeding rate on Carcass Analysis}

knowledge of the body composition of fish and factors affecting it allows the assessment of fish health, determination of efficiency of transfer of nutrients from the food to the fish make it possible to predictably modify carcass composition [38]. Proximate composition of whole fish body analysis showed significance differences in terms of dry matter and crude lipid with different feeding rate (Table 6). However, crude protein and ash not significantly different between tested feeding rate. On the other hand, whole fish body lipid was increased by the increasing feeding rate in treatments 5 and $7 \%$, without significance difference between the two feeding rates.

Table 6: Carcass analysis (Mean $\pm \mathrm{sd}, \mathrm{n}=3$ ) of tilapia fed on the experimental diets (\%w/w basis).

\begin{tabular}{|c|c|c|c|c|c|}
\hline \multirow{2}{*}{ Chemical analysis } & \multicolumn{4}{|c|}{ Feeding levels } & \multirow[b]{2}{*}{$7 \%$} \\
\hline & Initial & (3\%Control) & $1 \%$ & $5 \%$ & \\
\hline Dry matter (DM) & $23.56 \pm 0.25$ & $23.85^{\mathrm{c}} \pm 0.22$ & $22.61^{\mathrm{d}} \pm 0.21$ & $25.82^{\mathrm{b}} \pm 0.24$ & $26.7^{\mathrm{a}} \pm 0.22$ \\
\hline Crude protein (CP) & $15.0 \pm 0.16$ & $14.16^{\mathrm{a}} \pm 0.14$ & $13.95^{\mathrm{a}} \pm 0.12$ & $14.62^{\mathrm{a}} \pm 0.0 .15$ & $14.40^{\mathrm{a}} \pm 0.14$ \\
\hline Ether extract (EE) & $3.1 \pm 0.12$ & $4.06^{c} \pm 0.11$ & $3.0^{\mathrm{d}} \pm 0.1$ & $5.91^{\mathrm{a}} \pm 0.12$ & $6.70^{\mathrm{a}} \pm 0.11$ \\
\hline Ash & $5.45 \pm 0.22$ & $5.63^{\mathrm{a}} \pm 0.19$ & $5.66^{\mathrm{a}} \pm 0.2$ & $5.65^{\mathrm{a}} \pm 0.18$ & $5.60^{\mathrm{a}} \pm 0.16$ \\
\hline
\end{tabular}

Means in the same raw with different super script letters are significantly different $(P<0.05)$.

Significant differences $(\mathrm{P}<0.05)$ between fish fed 3 and $1 \%$ and the other two feeding rate (5and7\%), where $3 \%$ group revealed a moderate crude lipid and less value was obtained with $1 \%$ feeding rate. Dry matter was significantly higher at 7 and $5 \%$ while intermediate at 3 and $1 \%$ feeding rate. It revealed that increasing feeding rate can increase dry matter content. The present results were in line with the results obtained in tilapia by. But contrast to the results obtained by [9]. The present results from protein and ash were like the results obtained by $[28,39]$ in the same species. The increase in lipid content with 5 and $7 \%$ feeding rate were agree with the previous results in tilapia. However, other research recorded that lipid contents of tilapia not affected by feeding levels $[40,41]$. The difference between the present results and the previous studies maybe due to the different stage and condition of treated fish.

\section{References}

1. (2013) In: Stocker TF, D Qin, G K Plattner, M Tignor, SK Allen, etc. (eds), Climate Change 2013: The Physical Science Basis, Contribution of Working Group I to the Fifth Assessment Report of the Intergovernmental Panel on Climate Change. Intergovernmental Panel on Climate Change ( $1^{\text {st }}$ edn). Cambridge University Press, Cambridge, United Kingdom Pp. 1535.

2. Wuebbles DJ, DW Fahey, KA Hibbard, DJ Dokken, BC Stewart, etc. (2017) Climate Science Special Report: Fourth National Climate Assessment. US Global Change Research Program 1(1): 470.
3. Parker A (2013) Sea level trends at locations of the United States with more than 100 years of recording. Natural Hazards 65(1): 1011-1021.

4. Church J A, White N J (2011) Sea-Level Rise from the Late 19th to the Early 21st Century . Surveys in Geophysics 32(4): 585-602.

5. Woodworth P L, Player R (2003) The permanent service for mean sea level: An update to the 21st century. Journal of Coastal Research 19(2): 287-295.

6. Nerem R S, Chambers D P, Choe C (2010) Estimating mean sea level change from the TOPEX and Jason altimeter missions. Marine Geodesy 33(S1): 435-446.

7. Leuliette E W, Nerem R S, Mitchum G T (2004) Calibration of TOPEX/ Poseidon and Jason altimeter data to construct a continuous record of mean sea level change. Marine Geodesy 27(1-2): 79-94

8. Stanev E V, Peneva E L (2001) Regional sea level response to global climatic change: Black Sea examples. Global and Planetary Change 32(1): 33-47.

9. Kopp R E, A C Kemp, K Bittermann (2016) Temperature-driven global sea-level variability inthe Common Era. Proceedings of the National Academy of Sciences 113: 1434-1441.

10. Kemp A C, BP Horton, JP Donnelly (2011) Climate related sea-level variations over the past two millennia. Proceedings of the National Academy of Sciences 108: 11017-11022.

11. Lu Qing, Zuo Juncheng, Wu Lingjun (2017) Low-frequency variation in sea level in the tropical Pacific. Acta Oceanologica Sinica 39(7): 43-52.

12. Merrifield MAA (2011) shift in western tropical Pacific sea level trends during the 1990s. Journal of Climate 24(15): 4126-4138. 
13. Zhang X J A Church (2012) Sea level trends, interannual and decadal variability in the Pacific Ocean. Geophysical Research Letters 4: 39-41.

14. Stammer D, Cazenave A, Ponte R M (2013) Causes for contemporary regional sea level changes. Ann Rev Mar Sci 5(1): 21-46.

15. Dieng H B, Cazenave A, B Meyssignac (2017) New estimate of the current rate of sea level rise from a sea level budget approach. Geophysical Research Letters 44(8): 3744-3751.

16. Shepherd A, Ivins E R, Barletta V R (2012) A reconciled estimate of icesheet mass balance. Science 338: 1183.
17. Chambers D P, Cazenave A, Champollion N, et al, 2017. Evaluation of the Global Mean Sea Level Budget between 1993 and 2014. Surveys Geophysics 38(1): 309-327.

18. Levitus S, Antonov J I, Boyer T P, H E Garcia,R A Locarnini (2005) Linear trends of zonally averaged thermosteric, halosteric, and total steric sea level for individual ocean basins and the world ocean, (1955-1959)(1994-1998). Geophysical Research Letters 32(16).

19. Wang Gongjie, Cheng Lijing, Boyer T (2017) Halosteric sea level changes during the argo era. Water 9(7): 484

\section{Your next submission with Juniper Publishers} will reach you the below assets

- Quality Editorial service

- Swift Peer Review

- Reprints availability

- E-prints Service

- Manuscript Podcast for convenient understanding

- Global attainment for your research

- Manuscript accessibility in different formats

( Pdf, E-pub, Full Text, Audio)

- Unceasing customer service

Track the below URL for one-step submission https://juniperpublishers.com/online-submission.php 